\title{
Purification and Properties of an RNA Methylase Produced by Streptomyces azureus and Involved in Resistance to Thiostrepton
}

\author{
By JILL THOMPSON* AND ERIC CUNDLIFFE \\ Department of Biochemistry, University of Leicester, Leicester LE1 $7 R H$
}

(Received 25 November 1980)

\begin{abstract}
Ribosomes of Streptomyces azureus, the thiostrepton producer, are resistant to the drug due to the action of an RNA-pentose methylase which acts on 23S ribosomal RNA. This enzyme, which is active in vitro on ribosomal RNA from other bacteria (e.g. Escherichia coli), employs $S$-adenosylmethionine as cofactor to catalyse the formation of a single residue of 2 '- $O$-methyladenosine. The 'thiostrepton-resistance methylase' has been purified 11000 -fold (although not to homogeneity) and eluted from gel filtration columns with an apparent molecular weight of 35000 to 38000 . The preferred substrate for the methylase was phenol-extracted 23S RNA. In contrast, mature 50S ribosomal subunits were unaffected by the enzyme although protein-deficient core particles, prepared by exposure of ribosomes to $\mathrm{LiCl}$, retained partial substrate activity. Significantly, the methylase was inactive on the complex of 23S RNA with ribosomal protein $\mathrm{L} 11$.
\end{abstract}

\section{INTRODUCTION}

The antibiotic thiostrepton is produced by Streptomyces azureus and inhibits bacterial protein synthesis by binding virtually irreversibly to the $50 \mathrm{~S}$ ribosomal subunit. Previously (Cundliffe, 1978; Cundliffe \& Thompson, 1979) we have demonstrated the presence in $S$. azureus of RNA-pentose methylase activity which leads to the production of $23 \mathrm{~S}$ ribosomal RNA (rRNA) containing a single residue of $2^{\prime}-O$-methyladenosine. Ribosomes containing such modified RNA fail to bind thiostrepton and thus are totally resistant to the action of the drug.

The mode of action of thiostrepton is reviewed elsewhere (Cundliffe, 1979) but, in summary, the drug inhibits various processes associated with the 'GTP hydrolysis centre' of the ribosome, including the binding of guanine nucleotides, of elongation factor proteins and of tRNA. Recently, we demonstrated that a tight binding site for thiostrepton can be constructed in vitro using only $23 \mathrm{~S}$ rRNA and ribosomal protein L11 (Thompson et al., 1979).

Accordingly, we wished to examine in detail the relationship between the site of action of the RNA-pentose methylase (referred to, for convenience, as 'thiostrepton-resistance methylase') and the binding sites within 23S rRNA of protein L11 and other components of the ribosomal GTPase centre. To do this, however, a preparation of the enzyme free from contaminating methylases and nucleases would be required whereas, in previous studies, we merely employed crude extracts of $S$. azureus as the source of the enzyme.

In the present paper, we describe a procedure for the substantial purification of the 'thiostrepton-resistance methylase' of $S$. azureus and we discuss the substrate specificity and various other properties of the enzyme. 


\section{METHODS}

Reagents. S-Adenosyl-L- $\left[\right.$ methyl $\left.-{ }^{3} \mathrm{H}\right]$ methionine ([methyl $\left.\left.-{ }^{3} \mathrm{H}\right] \mathrm{SAM}\right)$ was obtained from The Radiochemical Centre, Amersham at a specific radioactivity of $500 \mathrm{mCi} \mathrm{mmol}^{-1}\left(18.5 \mathrm{GBq} \mathrm{mmol}^{-1}\right)$. [ $\left.{ }^{35} \mathrm{~S}\right]$ Thiostrepton was prepared as described previously (Dixon et al., 1975). Protein molecular weight standards for gel electrophoresis and fine chemicals were obtained from Sigma. Sephadex G-100 (superfine grade), DEAE-Sephadex A-50 and activated CH-Sepharose 4B were from Pharmacia. Linkage of $S$-adenosyl-homocysteine to activated Sepharose was carried out as described by Izzo \& Gantt (1977). Ribosomal protein L11 of Escherichia coli was generously provided by Dr J. Dijk and was prepared as described by Dijk \& Littlechild (1979).

Growth of S. azureus and cell breakage. Spores of Streptomyces azureus ATCC 14921 were used to inoculate $12 \times 1$ litre broth containing (per litre) $10 \mathrm{~g}$ peptone, $5 \mathrm{~g}$ yeast extract and $5 \mathrm{~g}$ glucose. Growth was continued for $18 \mathrm{~h}$ with shaking at $30^{\circ} \mathrm{C}$. Cells were harvested by filtration using Whatman no. 1 paper on a Buchner funnel and then washed three times by resuspension in, and centrifugation from, RS buffer $(10 \mathrm{~mm}$-Tris/ $\mathrm{HCl}, \mathrm{pH} 7.6$ at $20^{\circ} \mathrm{C}, 10 \mathrm{mM}^{-\mathrm{MgCl}_{2}}, 50 \mathrm{mM}-\mathrm{NH}_{4} \mathrm{Cl}, 3 \mathrm{~mm}$-2-mercaptoethanol). Further manipulations of cells and extracts were carried out at 0 to $4{ }^{\circ} \mathrm{C}$. Washed cells (total yield $53 \mathrm{~g}$ wet wt) were resuspended in ice-cold RS buffer at about $0.5 \mathrm{~g}$ wet wt ml $\mathrm{m}^{-1}$ and passed twice through a chilled French press at 70 to $80 \mathrm{MPa}$. Deoxyribonuclease $\left(5 \mu \mathrm{g} \mathrm{ml}^{-1}\right.$ final concentration) was added between pressings. Then, unbroken cells and debris were removed by centrifuging at $30000 \mathrm{~g}$ for $60 \mathrm{~min}$, and post-ribosomal supernatant $(111 \mathrm{ml}$ total volume) was obtained by centrifuging the extract at $100000 \mathrm{~g}$ for $3 \mathrm{~h}$.

Fractionation of proteins by salt precipitation. Post-ribosomal supernatant from $S$. azureus was stirred at $4{ }^{\circ} \mathrm{C}$ and solid $\left(\mathrm{NH}_{4}\right)_{2} \mathrm{SO}_{4}$ was added batchwise to give $50 \%$ saturation. After a further 30 min, precipitated material was collected by centrifugation at $30000 \mathrm{~g}$ for $30 \mathrm{~min}$. The supernatant was then brought to $70 \%$ saturation with $\left(\mathrm{NH}_{4}\right)_{2} \mathrm{SO}_{4}$, again stirred for $30 \mathrm{~min}$ at $4{ }^{\circ} \mathrm{C}$ and the precipitate was collected by centrifugation as previously. Finally, the resultant supernatant was brought to $100 \%$ saturation with $\left(\mathrm{NH}_{4}\right)_{2} \mathrm{SO}_{4}$ and again the precipitate was collected. Precipitates were each re-dissolved in $4 \mathrm{ml} \mathrm{RS}$ buffer containing $10 \%(\mathrm{v} / \mathrm{v})$ glycerol (RSG buffer), and $\left(\mathrm{NH}_{4}\right)_{2} \mathrm{SO}_{4}$ was removed by dialysis against $4 \times 2$ litre $\mathrm{RSG}$ buffer at $0{ }^{\circ} \mathrm{C}$. All three fractions were then assayed for gross methylase activity and also for the specific 'thiostrepton-resistance methylase' (see below). RNA methylase activity was detected among proteins precipitated both in the 0 to $50 \%$ and in the 50 to $70 \%$ saturation range although 'thiostrepton-resistance methylase' activity was present almost exclusively in the latter fraction. Accordingly, only this material was retained for further purification.

Gel filtration. Following salt precipitation, the protein fraction containing 'thiostrepton-resistance methylase' activity was applied to a column $(60 \times 2 \mathrm{~cm})$ of Sephadex G-100 (superfine grade) previously equilibrated with RSG buffer and calibrated with protein molecular weight standards. The column (bed volume $150 \mathrm{ml}$ ) was eluted with RSG buffer at $3 \mathrm{ml} \mathrm{h}^{-1}$ and fractions $(5 \mathrm{ml}$ ) were again assayed both for RNA methylase activity and for 'thiostrepton-resistance methylase' activity. These were recovered as coincident single peaks of activity eluting together with proteins in the molecular weight range 35000 to 38000 (elution volume 250 to $275 \mathrm{ml}$ ).

Ion-exchange chromatography. Following gel filtration, pooled column fractions ( $25 \mathrm{ml}$ ) containing 'thiostrepton-resistance methylase' activity were loaded directly on to a column $(30 \times 2.5 \mathrm{~cm})$ of DEAE-Sephadex A-50 previously equilibrated with TMG buffer $\left[10 \mathrm{mM}\right.$-Tris $/ \mathrm{HCl} \mathrm{pH} 7.6$ at $20{ }^{\circ} \mathrm{C}, 10 \mathrm{mM}-\mathrm{MgCl}_{2}, 10 \%(\mathrm{v} / \mathrm{v})$ glycerol, $3 \mathrm{~mm}$-2-mercaptoethanol] containing $200 \mathrm{~mm}$-sodium acetate. The column was eluted at $5 \mathrm{ml} \mathrm{h}^{-1}$ with $750 \mathrm{ml}$ TMG buffer containing $200 \mathrm{mM}$-sodium acetate and then with $500 \mathrm{ml}$ TMG buffer in which the content of sodium acetate increased from 200 to $500 \mathrm{mM}$ as a linear gradient of concentration. The eluate was passed through an LKB Uvicord analyser and the ultraviolet absorbance was monitored continuously at $280 \mathrm{~nm}$. Bulk protein evidently passed through the column unretarded and most of the remainder was displaced by sodium acetate in the concentration range 250 to $350 \mathrm{mM}$. Fractions $(5 \mathrm{ml})$ of the eluate were screened both for RNA methylase activity and for 'thiostrepton-resistance methylase' activity. These were eluted together at around $400 \mathrm{~mm}$-sodium acetate (conductivity range 9 to $10 \mathrm{~m} \Omega^{-1}$ ) in a total volume of approximately $20 \mathrm{ml}$. The appropriate column fractions were pooled, dialysed against $3 \times 2$ litre RS buffer containing $20 \%(\mathrm{v} / \mathrm{v})$ glycerol and stored as multiple samples at $-70^{\circ} \mathrm{C}$.

Assay of RNA methylase activity. This method was used routinely for screening column fractions and also for determination of the specific activity of the 'thiostrepton-resistance methylase' at various stages of purification. For this purpose we employed as substrate total ribosomal RNA extracted from $E$. coli ribosomes with phenol. On other occasions, as described in the text and in the legend to Fig. 1, alternative substrates were employed. These included purified ribosomal RNA species, ribosomal core particles and ribosomal subunits. Typical incubation mixtures contained $20 \mathrm{pmol}$ ribosomal RNA, $2 \cdot 5 \mu \mathrm{Ci}$ [methyl $\left.{ }^{3} \mathrm{H}\right] \mathrm{SAM}$ and $20 \mu \mathrm{l}$ individual column fractions (or partially purified enzyme preparation) in $100 \mu \mathrm{l}$ of buffer composed of $50 \mathrm{~mm}-\mathrm{N}$-2-hydroxyethylpiperazine-

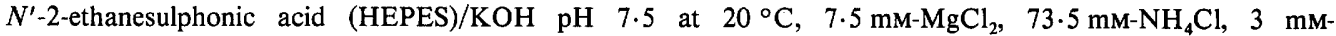
2-mercaptoethanol. Control incubations lacking RNA substrate were also included. After 15 min at $35^{\circ} \mathrm{C}$, samples $(20$ or $40 \mu \mathrm{l})$ were removed into ice-cold $5 \%(\mathrm{w} / \mathrm{v})$ trichloroacetic acid (TCA) and held at $0{ }^{\circ} \mathrm{C}$ for $30 \mathrm{~min}$ before precipitates were collected on glass-fibre discs (Whatman GF/C). After washing with $20 \mathrm{ml} 5 \%(\mathrm{w} / \mathrm{v}$ ) 
TCA, the discs were dried and their radioactivity was estimated by liquid-scintillation spectrometry. Counting efficiency was approximately $31 \%$ so that 1 pmol $\left[{ }^{3} \mathrm{H}\right]$ methyl radioactivity was represented by 340 c.p.m.

Assay of 'thiostrepton-resistance methylase' activity. Thiostrepton binds virtually irreversibly to $23 \mathrm{~S}$ rRNA or ribosomal core particles provided protein L11 is present. Similarly, the drug binds to mature $70 \mathrm{~S}$ or $50 \mathrm{~S}$ ribosomal particles which normally contain protein L11. This assay utilizes the novel observation that the action of the 'thiostrepton-resistance methylase' so modifies rRNA (or ribonucleoprotein particles) that, following the addition of protein $\mathrm{L} 11$, thiostrepton is not bound. Incubation mixtures were similar to those employed in the assay of RNA methylase activity except that non-radioactive SAM $(0.5 \mathrm{mM})$ was used as cofactor. Typically, 20 pmol substrate (rRNA or ribonucleoprotein particles) was employed. After $15 \mathrm{~min}$ at $35^{\circ} \mathrm{C}$, protein L11 (50 pmol) and $\left.{ }^{35} \mathrm{~S}\right]$ thiostrepton $(40 \mathrm{pmol})$ were added and incubation was continued for a further $15 \mathrm{~min}$ at $20^{\circ} \mathrm{C}$. Binding of thiostrepton was estimated, following removal of unbound drug by adsorption to activated charcoal, as previously described (Thompson et al., 1979). Controls lacking SAM or protein L11 were included. $\left[{ }^{35}\right.$ S $]$ Thiostrepton was used at 220 to 70 c.p.m. pmol $^{-1}$ as decay proceeded.

Estimation of protein. In determining the specific activity of enzyme preparations, protein was estimated using Coomassie Blue as described by Spector (1978), with bovine serum albumin as standard.

\section{RESULTS}

\section{Purification of the 'thiostrepton-resistance methylase'}

The steps employed and the purification factors achieved are listed in Table 1. It is important to note that, using rRNA from $E$. coli as substrate, it was only possible to detect rRNA methylases of $S$. azureus which were lacking a counterpart in $E$. coli. Evidently, other such enzymes were separated from the 'thiostrepton-resistance methylase' by salt precipitation. However, given the availability of unmethylated rRNA, other methylases might well have been detected following gel filtration or ion-exchange chromatography and might still have been present in our final preparation. Thus, although we have purified the enzyme substantially, it is still not homogeneous as judged by sodium dodecyl sulphatepolyacrylamide gel electrophoresis (results not given). In unsuccessful attempts to improve the degree of purification, we employed an affinity resin to which $S$-adenosyl-homocysteine was coupled but from which we were unable to elute active enzyme. We note, however (Table 2 ), that $S$-adenosyl-homocysteine is an exceedingly potent inhibitor of the enzyme and that the two interact with high affinity.

Notwithstanding this problem, the purified enzyme introduced only a single methyl group into total ribosomal RNA of $E$. coli (Fig. 1). Subsequent examination revealed that this occurred exclusively within $23 \mathrm{~S}$ rRNA and resulted in the production of a single methylated product, namely $2^{\prime}-O$-methyladenosine (data not given, but see Cundliffe \& Thompson, 1979).

\section{Substrate specificity}

As shown in Fig. 1, the time courses of methylation of ribosomal RNA and of loss of thiostrepton-binding capability were closely similar. We emphasize this point here since previously (Cundliffe \& Thompson, 1979) similar effects were observed, but only with crude enzyme acting on $3 \mathrm{M}$ - $\mathrm{LiCl}$ core particles over a much longer time course. Evidently (Fig. 1), the preferred substrate for the resistance methylase was naked 23S rRNA; the mature 50S ribosomal subunit was completely unaffected. These observations would be rationalized if binding of ribosomal proteins to $23 \mathrm{~S}$ rRNA during assembly of the 50S subunit were to block the action of the enzyme. Protein L11 was highly effective in this respect (Fig. 1) suggesting that the site of action of the methylase and the binding site for protein L11 should be, in some way, related. Conceivably, the former falls within the latter. In contrast, other ribosomal proteins did not affect methylation so markedly. Thus, $1 \mathrm{M}$ - $\mathrm{LiCl}$ core particles, which contain approximately 20 out of the total of 32 proteins of the 50S ribosomal subunit (Homann \& Nierhaus, 1971), still retained substrate activity although longer incubations with the enzyme were required for complete methylation (Fig. 1). Significantly, however, $1 \mathrm{M}$ - $\mathrm{LiCl}$ cores do not contain protein L11. Removal of extra proteins (e.g. in production of $3 \mathrm{M}$ - $\mathrm{LiCl}$ cores) 
Table 1. Purification of the 'thiostrepton-resistance methylase' from S. azureus

$\begin{array}{lcccccc}\text { Fraction } & \begin{array}{c}\text { Volume } \\ (\mathrm{ml})\end{array} & \begin{array}{c}\text { Total protein } \\ (\mathrm{mg})\end{array} & \begin{array}{c}\text { Total } \\ \text { activity* }\end{array} & \begin{array}{c}\text { Specific } \\ \text { activity } \dagger\end{array} & \begin{array}{c}\text { Purification } \\ \text { factor }\end{array} & \begin{array}{c}\text { Yield } \\ (\%)\end{array} \\ \text { somal supernatant } & 111 & 771.45 & 17.39 & 0.023 & - & - \\ \text { saturation }\left(\mathrm{NH}_{4}\right)_{2} \mathrm{SO}_{4} & 4 & 179.60 & 15.99 & 0.089 & 3.9 & 92 \\ \text { X G-100 } & 25 & 0.710 & 10.00 & 14.08 & 612 & 57.5 \\ \text { Sephadex A-50 } & 20 & 0.029 & 7.33 & 252.87 & 10994 & 42\end{array}$

${ }^{*}$ pmol methyl groups incorporated $\min ^{-1} . \quad \dagger$ pmol methyl groups incorporated $\min ^{-1}$ (mg protein $)^{-1}$.

\section{Table 2. Inhibition of 'thiostrepton-resistance methylase' activity}

\section{Inhibitor \\ (5 mM unless indicated)}

$S$-Adenosyl-homocysteine $(0.5 \mathrm{~mm})$

Methionine

Adenosine

Methionine + Adenosine

ATP

AMP

$\mathrm{KH}_{2} \mathrm{PO}_{4}$

$\mathrm{KCl}$

Thiostrepton
Binding of $\left[{ }^{35} \mathrm{~S}\right]$ thiostrepton following methylation* $(\%)$

\begin{tabular}{rr}
96 & 99 \\
0 & 0 \\
25 & 28 \\
27 & 27 \\
35 & 22 \\
27 & 28 \\
47 & 50 \\
0 & 1 \\
- & 1 \\
\hline
\end{tabular}

* Escherichia coli rRNA was incubated with SAM $(50 \mu \mathrm{M})$ plus methylase plus inhibitor prior to addition of protein $\mathrm{L} 11$ and $\left[{ }^{35} \mathrm{~S}\right]$ thiostrepton. In the absence of inhibitors, the stoichiometry of drug binding was 0.03 (taken as $0 \%)$. In the absence of SAM, the stoichiometry was $1.0(=100 \%)$.

$\dagger$ The stoichiometry of methylation in controls was 1.02 .

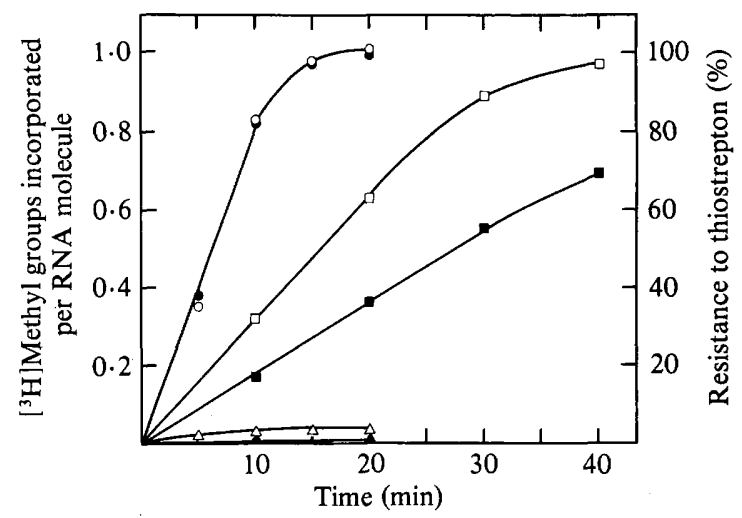

Fig. 1. Methylation of various substrates by the 'thiostrepton-resistance methylase'. RNA methylase activity: Substrates ( 70 to $80 \mathrm{pmol})$ were incubated with methylase $(10 \mu$ containing $15 \mathrm{ng}$ protein) plus [methyl ${ }^{3} \mathrm{H}$ ]SAM in a final volume of $200 \mu \mathrm{l}$. At intervals, duplicate samples $(20 \mu \mathrm{l})$ were removed into ice-cold TCA and the radioactivity in precipitates was determined as described in Methods. Results shown are the mean of three experiments. Substrates: $O$, total rRNA; $\square, 3 \mathrm{M}$-LiCl core particles; $\square$, $1 \mathrm{M}$-LiCl core particles; $\triangle$, rRNA with protein $\mathrm{L} 11 ; \Delta, 50 \mathrm{~S}$ ribosomal subunits. The complex of rRNA and protein $\mathrm{L} 11$ was formed by incubation at $25{ }^{\circ} \mathrm{C}$ for $15 \mathrm{~min}$ prior to addition of methylase and cofactor. 'Thiostrepton-resistance methylase' activity ( $)$ : Total rRNA was methylated as described above but using non-radioactive SAM $(0.5 \mathrm{mM})$ as cofactor. Binding of $\left[{ }^{35} \mathrm{~S}\right]$ thiostrepton to rRNA reconstituted with a twofold molar excess of protein $\mathrm{L} 11$ was determined as described in Methods. The stoichiometry of binding of $\left[{ }^{35} \mathrm{~S}\right]$ thiostrepton to non-methylated rRNA plus protein L11 was 1.02 . 


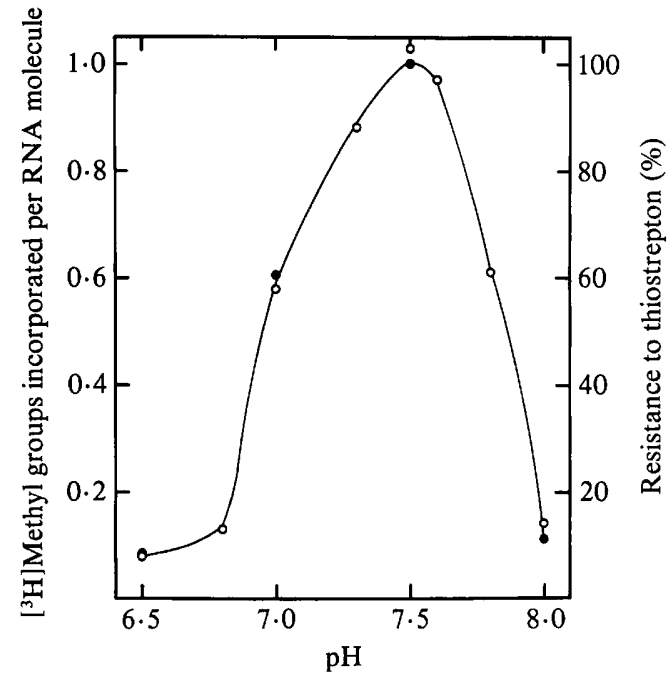

Fig. 2. Effect of $\mathrm{pH}$ on 'thiostrepton resistance methylase' activity. RNA methylase activity (O): Methylase $\left(2 \mu \mathrm{l}\right.$ containing $3 \mathrm{ng}$ protein) was incubated with rRNA $(20 \mathrm{pmol})$ and $\left[\right.$ methyl $\left.{ }^{3} \mathrm{H}\right] \mathrm{SAM}$ in a final volume of $100 \mu \mathrm{l}$ as described in Methods except that the $\mathrm{pH}$ was varied in the range $6 \cdot 5$ to 8.0 . Methylation was followed as the incorporation of $\left[{ }^{3} \mathrm{H}\right]$ methyl radioactivity into TCA-precipitable material. 'Thiostrepton-resistance methylase' activity (O): This was followed as described in Methods using $3 \mathrm{ng}(2 \mu \mathrm{l})$ methylase per assay, which was the minimal amount of enzyme required completely to abolish thiostrepton binding within $15 \mathrm{~min}$ at $35^{\circ} \mathrm{C}$ under optimal conditions.

improved the substrate activity. From these results we infer that 23S rRNA can of itself attain whatever conformation may be required for interaction with the methylase, without any requirement for ribosomal protein to maintain or create such secondary structure.

\section{Optimal conditions for methylase activity}

The 'thiostrepton-resistance methylase' showed a sharp $\mathrm{pH}$ optimum around 7.5 to 7.6 (Fig. 2) and was unstable below pH 6.0. The enzyme was quite active over a range of temperature $\left(30\right.$ to $\left.45^{\circ} \mathrm{C}\right)$ with fairly broad ionic optima $\left(\mathrm{Mg}^{2+}, 5\right.$ to $20 \mathrm{mM} ; \mathrm{K}^{+}$or $\mathrm{NH}_{4}^{+}, 50$ to $100 \mathrm{~mm}$ ). In determining these optimal conditions for activity, total ribosomal RNA of $E$. coli was employed as substrate together with $\left[\right.$ methyl $\left.{ }^{3} \mathrm{H}\right] \mathrm{SAM}$ as cofactor. Thereafter, assays were routinely carried out at $\mathrm{pH} 7.5$ and at $35^{\circ} \mathrm{C}$ in the presence of $7.5 \mathrm{mM}-\mathrm{Mg}^{2+}$ and $73.5 \mathrm{mM}^{-\mathrm{NH}_{4}^{+}}$. Under such conditions, we determined an apparent $K_{\mathrm{m}}$ value for SAM of 1.5 $\pm 0.3 \times 10^{-4} \mathrm{M}$.

\section{Inhibition studies}

Several compounds were examined for their ability to inhibit the action of the purified enzyme on $E$. coli $23 \mathrm{~S}$ rRNA (Table 2). Firstly, using $\left[\right.$ methyl $\left.-{ }^{3} \mathrm{H}\right] \mathrm{SAM}$ as cofactor, we followed directly the effects of inhibitors on methylation. Secondly, with unlabelled SAM as cofactor, we examined their effects on 'thiostrepton-resistance methylase' activity. Most notable were the effects of $S$-adenosyl-homocysteine which proved to be a potent inhibitor of either activity $\left(K_{\mathrm{i}}\right.$ approximately $\left.5 \times 10^{-7} \mathrm{M}\right)$. Various compounds, including methionine, adenosine and thiostrepton were only moderately effective as inhibitors, even when present in 100 -fold molar excess over SAM. At similar input, phosphate gave around $50 \%$ inhibition although at one-tenth this level there was no inhibitory effect (results not given). We have no ready explanation for this observation. 


\section{DIS CUSSION}

That methylation of rRNA can influence the response of ribosomes to antibiotics has been recognized for some time. The first documented example concerned resistance to kasugamycin in $k s g A$ strains of $E$. coli. These organisms lack the geminal pair of $N^{6}, N^{6}$-dimethyladenine residues which normally occur close to the $3^{\prime}$-terminus of bacterial 16S rRNA (Helser et al., 1971). However, when core particles from 30S ribosomal subunits of $k s g A$ strains were methylated in vitro using extracts of wild-type and subsequently reconstituted with split proteins, the resultant ribosomes were sensitive to kasugamycin (Helser et al., 1972). Two residues of $N^{6}, N^{6}$-dimethyladenine had been inserted in the usual positions in 16S rRNA.

In contrast, specific 'overmethylation' of 23S rRNA determines the 'MLS'-resistance phenotype in certain clinical isolates of staphylococci and streptococci. Such organisms are resistant to macrolides, lincomycin and streptogramin $\mathrm{B}$ due to the action of a plasmid-encoded methylase, whose production can be induced by subinhibitory concentrations of the macrolide erythromycin. The product of methylation is $N^{6}, N^{6}$ dimethyladenine which is not normally present in bacterial 23S rRNA (for a full discussion, see Weisblum, 1975). Interestingly, this residue also appears in 23S rRNA from Streptomyces erythreus, which produces erythromycin and is also resistant to MLS antibiotics (Graham \& Weisblum, 1979). Accordingly, it was suggested (but not proven) that the resistance characteristics of $S$. erythreus might be determined by an RNA methylase similar to that which is responsible for the MLS-resistance phenotype in staphylococci.

The first suggestion that antibiotic-producing organisms might be the source of some of the drug-resistance determinants, now commonly encountered in clinical isolates, came following a study of the phosphorylation of streptomycin by extracts of Streptomyces species which produce that drug (Walker \& Walker, 1970). Since then, a number of aminoglycosideproducers have been shown to possess antibiotic-inactivating enzymes similar to those present in bacteria harbouring $\mathrm{R}$ factors (Benveniste \& Davies, 1973). Significantly, streptomycin-producing organisms possess streptomycin-sensitive ribosomes hence, resistance to their product depends upon drug-inactivation (Piwowarski \& Shaw, 1979). In some cases, resistance might also depend on the permeability properties of the cell surface (Cella \& Vining, 1975). Similar considerations also apply to the streptomycetes which produce viomycin and the capreomycins (Skinner \& Cundliffe, 1980).

An alternative to drug inactivation as a means of self-defence is target-site modification and, as discussed above, such a mechanism might be operative in S. erythreus. However, resistance to thiostrepton in $S$. azureus, mediated via the RNA-pentose methylase characterized here (and referred to, for convenience, as the 'thiostrepton-resistance methylase'), remains as the only documented example of this stratagem which involves ribosome modification.

The fact that $23 \mathrm{~S}$ rRNA, but not the mature $50 \mathrm{~S}$ ribosomal subunit, is a substrate for the methylase implies that, in vivo, the enzyme acts on rRNA early in its existence, perhaps at the level of the primary transcription product. Moreover, the fact that ribosomes from S. azureus appear to be refractory to thiostrepton throughout the cell growth cycle and not merely during the phase of bulk antibiotic production (unpublished observations) strongly suggests that the resistance methylase is produced constitutively.

What is not clear, however, is whether the 'thiostrepton-resistance methylase' might fulfil some other cellular function in $S$. azureus in addition to conferring resistance to the produced antibiotic. That this enzyme can confer resistance to thiostrepton in vivo was demonstrated when the appropriate gene was cloned into Streptomyces lividans (Thompson et al., 1980); but whether this is the sole function of the enzyme is more difficult to establish. Conceivably, it might also be involved in thiostrepton production, although this seems improbable given the structure of the drug (Anderson et al., 1970). Otherwise, there remain considerable conceptual problems in relegating to serendipity the acquisition of thiostrepton production by 
an organism carrying an apparently useless (but appropriate) gene. The alternative hypothesis, that thiostrepton production and the resistance mechanism were acquired concurrently by $S$. azureus, does little to resolve the paradox.

This work was supported by a grant to E.C. from the M.R.C. We should like to thank Chris Dickenson for helpful discussions.

\section{REFERENCES}

Anderson, B., Hodgkin, D. C. \& Viswamitra, M. A. (1970). The structure of thiostrepton. Nature, London 225, 233-235.

Benveniste, R. \& Davies, J. (1973). Aminoglycoside antibiotic-inactivating enzymes in actinomycetes similar to those present in clinical isolates of antibiotic-resistant bacteria. Proceedings of the National Academy of Sciences of the United States of America 70, 2276-2280.

Cella, R. \& Vining, L. C. (1975). Resistance to streptomycin in a producing strain of Streptomyces griseus. Canadian Journal of Microbiology 21, 463-472.

Cundliffe, E. (1978). Mechanism of resistance to thiostrepton in the producing-organism Streptomyces azureus. Nature, London 272, 792795.

Cundliffe, E. (1979). Thiostrepton and related antibiotics. In Antibiotics vol. V-I, pp. 329-343. Edited by F. E. Hahn. Berlin: Springer-Verlag.

Cundliffe, E. \& Thompson, J. (1979). Ribose methylation and resistance to thiostrepton. Nature, London 278, 859-861.

DiJK, J. \& LitTlechild, J. (1979). Purification of ribosomal proteins from Escherichia coli under nondenaturing conditions. Methods in Enzymology 59, 481-502.

Dixon, P. D., Beven, J. E. \& Cundliffe, E. (1975). Properties of the ribosomes of antibiotic producers: effects of thiostrepton and micrococcin on the organisms which produce them. Antimicrobial Agents and Chemotherapy 7, 850-855.

Graham, M. Y. \& Weisblum, B. (1979). 23S ribosomal ribonucleic acid of macrolide-producing streptomycetes contains methylated adenine. Journal of Bacteriology 137, 1464-1467.

Helser, T. L., Davies, J. E. \& Dahlberg, J. E. (1971). Change in methylation of 16S ribosomal RNA associated with mutation to kasugamycin resistance in Escherichia coli. Nature New Biology 233, $12-14$.
Helser, T. L., Davies, J. E. \& Dahlberg, J. E. (1972). Mechanism of kasugamycin resistance in Escherichia coli. Nature New Biology 235, 6-9.

HomanN, H. E. \& Nierhaus, K. H. (1971). Ribosomal proteins. Protein compositions of biosynthetic precursors and artificial subparticles from ribosomal subunits in Escherichia coli K12. European Journal of Biochemistry 20, 249-257.

Izzo, P. \& GANTT, R. (1977). Partial purification and characterization of an $N^{2}$-guanine RNA methyltransferase from chicken embryos. Biochemistry 16, 3576-3581.

Piwowarski, J. M. \& Shaw, P. D. (1979). Streptomycin resistance in a streptomycin-producing organism. Antimicrobial Agents and Chemotherapy 16, 176-182.

SkinNeR, R. H. \& CUNDliffe, E. (1980). Resistance to the antibiotics viomycin and capreomycin in the Streptomyces species which produce them. Journal of General Microbiology 120, 95-104.

Spector, T. (1978). Refinement of the Coomassie Blue method of protein quantitation. Analytical Biochemistry 86, 142-146.

Thompson, C. J., Ward, J. M. \& Hopwood, D. A. (1980). DNA cloning in Streptomyces: resistance genes from antibiotic-producing species. Nature, London 286, 525-527.

Thompson, J., Cundliffe, E. \& Stark, M. (1979). Binding of thiostrepton to a complex of $23 \mathrm{~S}$ rRNA with ribosomal protein L11. European Journal of Biochemistry 98, 261-265.

Walker, M. S. \& Walker, J. B. (1970). Streptomycin biosynthesis and metabolism. Journal of Biological Chemistry 245, 6683-6689.

Weisblum, B. (1975). Altered methylation of ribosomal ribonucleic acid in erythromycin-resistant Staphylococcus aureus. In Microbiology - 1974, pp. 199-206. Edited by D. Schlessinger. Washington, D.C.: American Society for Microbiology. 